\title{
Temsiller Bağlamında Umut Kavramı
}

\section{The Concept of Hope within the Context of Represantations}

\section{Bayram Dağlı}

Sanatta Yeterlik Öğrencisi, Ankara Hacı Bayram Veli Üniversitesi Lisansüstü Eğitim Enstitüsü Bileşik Sanatlar Ana Sanat Dalı

email: bdagli@@hotmail.com (DORCID ID: https://orcid.org/0000-0003-4573-3710

\section{Asuman Aypek Arslan}

Doç. Dr., Ankara Hacı Bayram Veli Üniversitesi Sanat ve Tasarım Fakültesi Görsel Sanatlar Bölümü email: asuman.aypek@hbv.edu.tr (DORCID ID: https://orcid.org/0000-0002-9400-2642

iThenticate` Bu makale bilimsel etik ve kurallara uygun hazırlanmış ve intihal incelemesinden geçirilmiștir.

Atıf (APA 6)/To cite this article

Dağlı, B., \& Aypek Arslan, A. (2020). Temsiller bağlamında umut kavramı. Atatürk Üniversitesi Güzel Sanatlar Enstitüsü Dergisi, 26(44), 19. doi: https://doi.org/10.35247/ataunigsed.675188

Makale Gönderim Tarihi/Received: 15/01/2020

Makale Kabul Tarihi/Accepted: $11 / 03 / 2020$

Makale Yayın Tarihi/Published: 19/03/2020

Review Article / Derleme Makalesi

\section{Öz}

Umut, insanoğlunun rahatsız olduğu duruma karşı harekete geçmesi ve içinde bulunduğu durumu değiştirme girişiminin edimidir. Umut eden birey ve toplum için hiçbir șey imkansız değildir. Kişi aktif bir beklenti içerisindedir. Bu aktif beklenti ulaşılmak istenen şey için eyleme dönüşür ve hayal etmenin ötesine geçer. İnsanoğlunu harekete geçiren olayların sayısız örneğine tarih içerisinde rastlamak mümkündür. Acı, keder, 1stırap yaratan durumlar krizlere ve trajedilere neden olarak, etkilenen kişileri içinde bulundukları durumu değiştirmek için eyleme geçirmis veya yer değiștirmelerine neden olmuștur. Taşıdıkları umutlar paralelinde hareket eden bu insanların veya toplumların durumuna felsefeciler ve sanatçılar kayıtsız kalmamıslardır. Felsefeciler insanı umut edilen șeye yönelten içsel gerekliliğin ardında yatan duyguları açıklamışlar, ressamlar da bu insanlık durumunu, yasanan olayları, insanlık vaziyetlerini doğrudan veya dolaylı olarak ilk elden görsel temsiller yoluyla eserlerinde ifade etmişlerdir. Bu çalışma da üç farklı sanatçının ortaya koymus olduğu yapitlardan hareketle, umut kavramının temsiller aracılığı ile eserlerin gerçekliği üzerinden nasıl temsil edildiği irdelenmiştir.

Anahtar Kelimeler: Umut, Görsel Temsil, Romantizm, Hatay, Mülteciler

\begin{abstract}
Hope is the act of taking action against the situation which human beings are disturbed from and attempting to change. Nothing is impossible for the hopeful individual and society. The person has an ongoing expectation. This ongoing expectation turns into action for what is to be achieved and goes beyond imagination. Numerous examples of events that have impellent power on human beings can be found in history. Pain situations bringing into the open pain and grief have forced the people affected by the pain and grief to take action and change their places. Philosophers and artists have not been indifferent to the situation of these people or societies acting in line with their hopes. Philosophers explained the emotions behind the inner necessity that led man to what was hoped for, and painters expressed this humanistic conditions, events, and situations of humanity directly or indirectly through first-hand visual representations. In this study, it is analyzed how the concept of hope is presented through the representations of the reality in the works of three different artists.
\end{abstract}

Keywords: Hope, Visual Representation, Romanticism, Hatay, Refugees

\section{Giriş}

Duygu ve düşüncenin temsilinin tarihi, insanın ortaya çıkması ile başlar. Temsiller kendi zamanının ruhunu; sözle, yazıyla ve görsellerle taşıyarak, farklı ifade biçimlerinde günümüze kadar gelmiştir. Görsel temsiller; sözlü ve yazılı olanı destekleyerek o dönemi duyumsamamızı ve algılayarak zihnimizde biçimlendirmemize ve anlamlandırmamıza yardım eder. Bu konuda, sanat alanına giren görsel temsillerin tarihi, Paleolotik dönemde mağaraların duvarlarına çizilen hayvan resimlerine kadar gitmektedir. "İlk mağara resimleri zengin bir kültürel miras imgesini ve muhtemelen nesilden nesile öyküleri taşıyabilen sembolik bir sürecin ilk reddedilemez ifadeleridir." (Humphrey, 1998, s. 165) Bu resimlerin niçin çizildiği birtakım çıkarımlarla varsayılabilir fakat tam olarak neyi ifade ettiği konusunda sunduğu ipuçları sınırlıdır. Keşfedilmiş bu ilk örneklerle başlayan görsel temsilin yolculuğu günümüze kadar sayısız kere biçimini değiştirerek ve gelişerek ulaşmıştır. 15. yüzyıla gelindiğinde sanat “...toplumsal ilişkilerin biriktiği bir çökeltidir. Bir yandan resmi yapan (...) ressam, diğer yandan onu yapmasını isteyen, bunun için gerekli mali kaynağı sağlayan (...) bir başkası vardır. İki taraf da ticari, dini, algısal yani geniş anlamıyla toplumsal kurum ve geleneklere bağlı çalışır” (Baxandal, 2015, s. 13). Dolayısıyla konu, toplum ve toplum içerisinde sanatçıya siparişi veren kişinin belirlediği hassasiyetler paralelinde ele alınmaktayd1. "Bu hassasiyetler; sanatta bireysel değerlerin azalması, sanatçı içselliğinin ve ne düşündüğünün değil, sanat eserinin neyi ifade etmek zorunda olduğu ile ilgilidir” (Read, 2018, s. 93).

15. yüzyılda hami (Himaye Sistemi) olarak adlandırılan kişilerin sanat üzerinde ciddi hakimiyetleri vardır. Ancak 16. yüzyılda ortaya çıkan kentli (Burjuva) grubun himayesi kuvvetlenmeye başlayacaktır (Burke, 2003, s. 80). 
Rönesans aydınlanması, sanatçıya kendini ifade etmede tam bir özgürlük getirmemiştir. Read'ın deyişiyle özgünlük "kendini ifade etme durumu, pazarlanabilir bir mal olduğunda geçerlidir" (Read, 2018, s. 94). Bu dönemde sanatçının yeteneği ve görünür olanı betimlemedeki ustalığı onu pazarlanabilir ve ünlü kılar. Barok Sanat ile birlikte sekülerleşmeye başlayan sanat konuları, himaye sistemini temsil eden kişilerin yer değiştirmesi (Kilisenin yerini devlet, aristokrat ve tüccarlar almıştır.) ona görece bir özgürlük kazandırmış gibi görünse de, benzer kisitlamalar başka biçimlerde devam etmiştir. 16. ve 17. yüzyılda Hollanda'da ticaretin gelişmesi ile kayda değer finansal güce sahip olan zengin kesim sayesinde, sanatçının kendini ifade etmesinde, dolaylı bir özgürlüğü getirmiş gibi görünmektedir. "Hami ve himaye sistemindeki sipariş edilen 'parça anlayışı' yerini 'sanatçının eseri' anlayışına bırakmıştır” (Shiner, 2017, s. 189). Hollanda'da gelişen bu anlayışın tüm Avrupa'da yayılması biraz zaman alacaktır. Himaye sistemi, Fransız devrimi sonrasında burjuva kesiminin zorunlu birtakım nedenlerle ellerindeki sanat eserlerini piyasaya sürmeleri ile ortadan kalkmıştır.

Sanat akımları, değişen dünyanın (politik, toplumsal, ekonomik değişimler vs.) getirmiş olduğu toplumsal ve bireysel yapı değişimlerini içinde barındırır. Bu değişimlerin kendisi ile birlikte getirdiği yeni anlayışlar, toplumları değiştirerek bireyciliği ortaya çıkarmıştır. Bu değişimlerin sınırları uzun süre keskin şekilde birbirinden ayrılmamıştır. Çünkü devlet tekelli akademilerin sanat dünyasındaki hakimiyetleri ve yönlendiricilikleri (Özellikle Fransız ve İngiliz Akademileri) 1880’lere kadar baskın bir şekilde hissedilmiştir.

Sanatta bireyselliğin baskın hale gelmeye başlaması, estetiğin felsefeden ayrılması ve bir bilim olarak görülmesi, psikolojinin bir bilim dalı olarak ortaya çıkması, sanayileşme ve kentleşme ile birlikte toplumsal yapıdaki değişimler, 1800'lerde büyük dönüşümleri kaçınılmaz hale getirmiştir. Sanatçılar toplumsal, politik gelişmelere karşı kayıtsız kalmamış, bu gelişme ve değişimler karşısında kendi duyarlılıklarını, simge ve semboller vasıtası ile aktarmışlardır. Bu bireysellik sanatta konu, form ve içerikte de köklü değişimlere neden olmuştur. Sanat eserinde içeriği, sanatçının bireysel penceresinden gördüğü ve hissettikleri oluşturmaya başlamıştır. Toplum hafızasının en önemli göstergesi, yaşamlarını sürdürdükleri üretim tarzları, inançları, hissettiklerini ifade ederken, somut olarak geriye bıraktıkları simge ve sembolleri olmuştur. 18. yüzyıl'a kadar belirgin bir şekilde dinin yönlendiriciliğinde biçimsel temsilini ortaya koymuş olan sanatlar, Romantizm ile perçinlenmiş yerini bireysel düşünce ve anlayışlara bırakmış, sanatçının içselliğini ön plana çıkarmıştır.

1. Dünya savaşının arifesinde Alman toplumunun duygusal karakterinden ortaya çıkan Ekspresyonizm, sanatın, değişen, dönüşen ve bozulan yapılara karşı bir dışavurum aracı olarak kullanılmasını sağlamıştır. Sanat artık sanatçının ruhsallığıdır. Yıkılan imparatorluklar, kurulan devletler, yeniden çizilen sınırlar, gözlemlemek, haber vermek, ulaşmak, belgelemek ve birbirini yok etmek için geliştirilen teknolojilerle gelişen yeni bakış açıları, sanat ve sanatçının ifade anlayışında, sanat yapıtını oluşturan tüm öğelerinde dönüşmesini sağlamıştır. Çağın gerekleri doğrultusunda sanattaki bu dönüşümler sanatçının ifade etmek istediğine daha da yaklaşmasını sağlamıştır. Dünyadaki bu dönüşümler, kitlelerin hassasiyetlerini ve duyarlılıklarını arttırmıştır. Bu etkiler altında kalan toplumlar, kendilerine yeni çıkış yolları aramış, tehlikeli hissettikleri durumlardan kaçmışlardır. İnsan yaradılışının bir gereği olarak hayal etmenin ötesine geçen, onları her zaman harekete geçiren taşıdıkları umutları olmuştur. Tarihte uluslar, toplumlar, topluluklar, kişiler umutları paralelinde harekete geçmiş ve fiili olarak olumlu veya olumsuz sonuçlarına katlanmışlardır.

Sanat tarihinde, dünyada yaşanan gerçeklikler üzerinden kitleleri ve kişileri harekete geçiren umut kavramını betimlemek, bireyselleşmiş sanatçının ortaya çıktığı 1800'lerde Romantizm ile başlar ve günümüzde de devam eder.

\section{Yöntem}

Araştırma; nitel araştırmalar arasında yer alan betimsel bir çalışmadır. Araştırma; sanat eserlerine konu olmuş "Umut" kavramının görsel temsiller aracılığıyla, tarihsel bağlantılar ve felsefik görüşler paralelinde açıklanmasına dayalıdır. Bu kapsamda görsel ve yazılı kaynaklar taranarak araştırmanın bulguları oluşturulmuştur. Araştırma ortaya konulurken analitik bir yöntem izlenmiş, içeriğin genel çerçevesi konulduktan sonra literatür taraması yapılmış ve umudu konu edinmiş sanatçılar tespit edilerek hangi sanatçıların araştırmanın içeriğine alınacağına karar verilmiştir. Araştırmada; 19. ve 20. yy’ın toplumsal yapıları, sanat ortamı ve anlayışı, etken ve edilgen yapısı içinde umut kavramı, Gericault'un “Medusa'nın Salı”, Çallı'nın “Hatay'ın Anavatan'a Hasreti” ve Longo'nun "İsimsiz (Denizde Sal)” adlı eserleri üzerinden ele alınarak incelenmiştir.

\section{Bulgular}

\subsection{Umut Kavramı Üzerine}

Umut kavramı kişinin, topluluğun yaşamındaki olay ve durumlarla ilgili olumlu sonuçlar çıkabileceği ihtimaline dair duygusal inancı olarak tanımlanabilir (Gülten, 2014). Türk Dil Kurumu; ("Türk Dil Kurumu”, 2019) umut kelimesini ummaktan doğan duygu, ümit, bu duyguyu veren kimse veya olacağı düşünülen şey olarak tanımlar. 
Umudun bir duygu veya düşünce biçimi olarak geleceği işaret ettiği görülür. Gerçekte umut geçmişte öğrenilir, anın şartları içerisinde geleceği işaret eder. Şu an için kişiye belli bir yön verir, motivasyonunu canlı tutar, yapmak istediği şey için harekete geçirir. Mevcut duruma dair hoşnutsuzluğu, rahatsızlığı ortadan kaldırmak, geleceğe dair kararlar vermek üzerine kuruludur. Bir bakıma umut kavramı ile gelecek inşa edilir (Toral, 2019). Umut kavramı daha çok felsefecilerin üzerinde durduğu bir konudur. Felsefeciler bu kavrama bir duygu ögesi olarak bakarlar. Aristo, Platon, Spinoza gibi felsefeciler tarafindan umut, insanlar için zararlı bir kavram olarak görülmüştür. Platon umudun haz ögesi taşıdı̆̆ı, Aristo'da umudun aldatıcı olabileceğinden hareketle temkinli yaklaşmıştır. Umuda pozitif bakan düşünürlerin başında Philo gelmiştir. "Ona göre umut, insan ruhunun sahip olduğu en değerli şey olmanın yanı sıra, Tanrı'nın insanın rasyonel ruhuna yerleştirdiği ilk şeydir.” Kant'a göre ise insan; sadece yapan, eden, enformatik bilgiyi işleyen bir yapıya sahip değildir. İnsanın tüm bunları yapmasının yanı sıra umut eden bir varlık olduğunu ileri sürer. İnsanın, seçimleri sonucunda harekete geçireceği eylemlerinin onu nereye ve hangi sonuçlara götüreceğini bilmek isteyen bir yapıya sahip olduğunu düşünür (Tan, 2014, s. 51-53).

Gabriel Marcel'e göre; kişi kendisine ve dünyaya yabancılaşmayı reddederek hareket edebileceği bir çizgi çizer. Bu belirlediği çizgi, onu nihai olarak ulaşmak istediğine kavuşturacak veya yolunu kaybettirecektir. Kişi umut ve umutsuzluk arasında seçim yaparak kendi maddi veya duygusal varlığını onaylar veya reddeder. Kişinin umuda yönelimi kendini gerçekleştirme ile de ilgilidir. Kişi umut yolu ile kendi benini merkeze alır ya da bu duygudan yoksun çaresizliğe, umutsuzluğa düşer. Umutsuzluk, çaresizlik olmadan umut gerçek değerini bulamaz. Kişi umut veya umutsuzluk arasında seçim yapar. Bu seçim onun kurtuluşu veya kayboluşu anlamına gelir. Umut, kişinin kendini gerçekleştirme yolundaki onayıdır (Koç, 2008, s. 172-192).

Umudu tanımlamak sözlüklerin, umut kavramını yorumlamak, temellendirmek, insan varlığı üzerinden açıklamasını yapmak felsefecilerin, kavramın insanın iç dünyasındaki yerini açıklamak psikologların işidir. Ancak umut kavramı sadece bunlar üzerinden açıklandığında kavramın içinin teorik olarak doldurulduğu görülür. Umut kavramını betimlemek, görünür kılmak, hissettirmek ise sanat ve sanatçının işi olmuştur.

\subsection{Trajediden Doğan Umut: Medusa'nın Salı}

19. yüzyıldaki belli bir zaman aralığını değil, tüm yüzyılın sürecini etkileyen ana akım Romantizmdir. Tüm kıta Avrupa'sını sadece sanat alanında değil, diğer çoğu alanı da etkilemesiyle yoğun olarak hissedilir. "Romantizm, Aydınlanma akılcılığına karşı bir tepki olarak gelişen bireyin, sanatın ve hukukun vs. özgürleşmesini ifade eder" (Russ, 2011, s. 330). Romantizm veya 19. yüzyıl aynı zamanda 20. yüzyıl'ın düşünsel ve bireyci temsilinin temelini oluşturacak ana fikirlere sahiptir. Birçok yeni düşünür ve düşüncenin (Comte, Hegel, Feuerbach vs.) ortaya çıktığı ve tüm Avrupa'yı etkilediği görülür. Bu dönemde Fransa'da ise Napoleon Bonapart döneminin 1814 'te sona ermesinden sonra Bourbon Restorasyon dönemi yaşanmaktaydı. Yapılan seçimi Ultralar kazanmış, 1lımlı kralcıların oluşturduğu bir meclis oluşturulmuş, daha istikrarlı bir dönem yaşanmaya başlamıştır. ${ }^{1}$

Fransa, 1800'lerin başından itibaren deniz aşırı topraklarda sömürgeleştirme faaliyetlerine girişmiştir. Savaş kabiliyetini arttırmış, sömürgeler bulmak amacıyla keşif seferlerine çıkmıştır (Uygur \& Uygur, 2014, s. 274). 1816 yılında böyle bir keşif sırasında 'Medusa' isimli Fransız firkateyni, Moritanya açıklarında kayalara oturarak büyük bir trajedinin yaşanmasına neden olmuştur.

Senegal'e keşif seferi için gönderilen bu firkateyn (Medusa), bir korvet, bir brik ve birde çektiriden oluşan Fransız konvoyu, okyanusta çıkan sert rüzgarlar, denizcilik konusunda yetkin olmayan kişilerin komutası sonucunda dağılır. 'Medusa' sahile yakın bir rota izlerken, Arguin² kayalıklarına oturur kurtarılamayacağı anlaşılınca da bir sal yapılarak tüm yolcuların tahliyesine karar verilir. Herkesin bineceği kadar sandal olmayınca, yapılacak sal mevcut sandallar tarafından çekilecek ve bu sayede kıyıya ulaşacaklardır.

Yapılan salın uzunluğu 20 metre, genişliği de 7 metreydi. Sal'a 120'si asker biri kadın, 29 denizci ve bir yolcu olmak üzere toplamda 150 kişi binmiştir. Sal gemiden uzaklaştıktan sonra sandallara bağlı olan ipler bir şekilde koparak okyanusta başıboş sürüklenmeye başlamıştır. Okyanustaki firtınalar, salın üzerindeki insanların huzursuzlukları, karşılıklı çarpışmalar, kurtulmaya dair umutların yitirilişi gibi nedenlerle, salın üzerinde sadece 15 kişi kalmıştır. Bu kişiler, salın denizde başıboş sürüklenmesinin 13. günü okyanusta seyreden bir gemi (Argus) tarafindan kurtarılmıştır (Barnes, 2018, s. 22-46).

Gemide ve salda yaşananlar uluslararası bir olaya dönüşür, gemide olanlar, kaptanın deneyimsiz olmasına bağlanır ve kaptanın da mevcut kralın atadığı öne sürülür. Bu söylentiler devrimden sonra yeniden kurulan monarşik yapıya ve ülkeye dönen aristokrat kesime duyulan öfkeden de kaynaklanmaktadır. Bu güncel durum halkı harekete

\footnotetext{
${ }^{1}$ 1814-1830 yılları arasını içeren Bourbon Restaorasyon dönemi Fransız toplumunda liberal ve muhafazakarlar arasında bir uzlaşma dönemidir. Düzenin sağlanması için birçok tutuklama ve idamlarında gerçekleştirildiği bir aralıktır. Bakınız: https://resources.saylor.org/wwwresources/archived/site/wp content/uploads/2011/05/ Bourbon-Restoration.pdf (13.11.2019).

${ }^{2}$ Arguin Körfezi; (Fransızca: Baie d'Arguin) Moritanya'nın Atlantik kıyılarındaki körfez. Bakınız: https://www.wikizeroo.org/index.php?q=aHR0cHM6Ly9lbi53aWtpcGVkaWEub3JnL3dpa2kvQmF5X29mX0FyZ3Vpbg(Alintı Tarihi:
} 21/11/2019) 
geçirmek için itici bir güç olacaktı (Yılmazok, 2019). Dönemin ressamlarından Theodore Gericault'un böyle trajik güncel bir olay karşısında tepkisiz kalması beklenemezdi. $O$ halde sanatçı bu trajik felaketi, gerçeğine uygun görsel temsiller aracılığı ile nasıl betimlemeliydi. Başından sonuna kadar yaşanan trajik gerçekliği ortaya koymak için Theodore Gericault; kazayı, salın üzerindeki yaşanan olayları ve mucize kurtuluşu nasıl ve hangi açıdan ele alacakt1.

Dönem, Fransız Sanat Akademisinin (École des Beaux-Arts) halen egemen olduğu geleneksel-akademik bir anlayıştaydı. 1800'lerin başından itibaren geleneğe karşı çıkan ve bireysel eğilimleri paralelinde sanat eserleri üreten, akademiye başkaldırmış bağımsız sanatçı anlayışı da oluşmaya başlamıştı. École des Beaux-Arts 'ta Baron Guerin'in öğrencisi olacak olan Theodore Gericault, atlara olan merakı yüzünden sıklıkla derslerini aksatacak, arkadaşları ile atölyede girişmiş olduğu bir kavga yüzünden akademiden atılacaktır. "Ne yaparsam yapayım daha değişik bir şey yapmış olmayı istiyorum” (Hauser, 2006, s. 184) deyişinden hareket eden, Gericault; klasik ögretinin getirmiş olduğu tarihin betimleyiciliğine değil Romantizmin getirdiği bilinçaltı imgesine tekabül eden bir eser yaratmıştır. 'Medusa'nın Salı' (Görsel 1) konusunu tarihten değil güncel bir konudan almıştır. Sanatçı, gerçeklerden, tanıklıklardan, deneyimlerden yola çıkarak o an orada yaşananlara dair duygusal atmosferi renklerle ve biçimlerle ifade etmeye çalışmıştır.

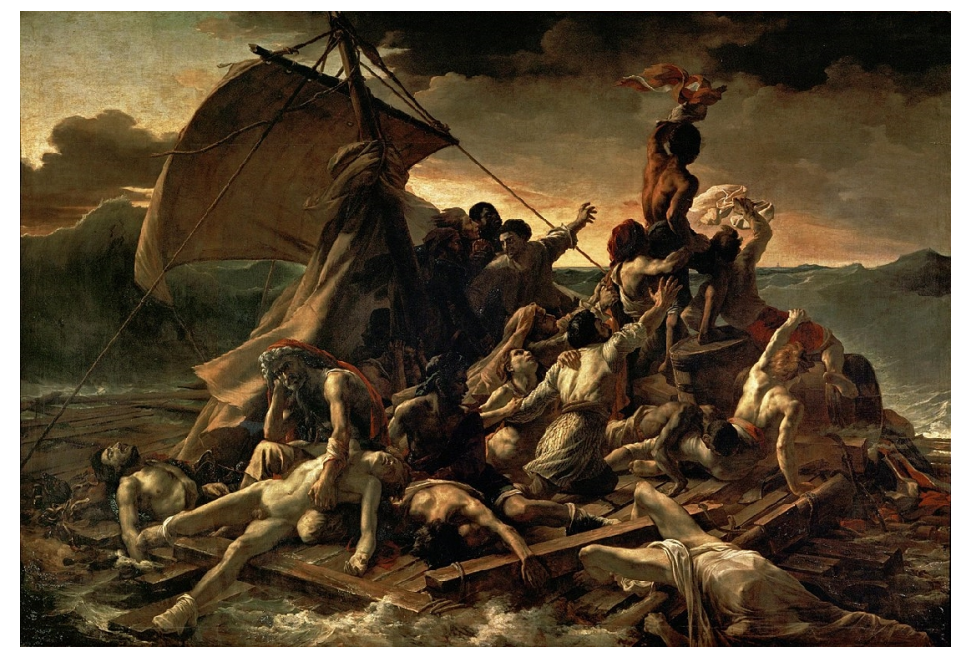

Görsel 1. Theodore Gericault, “Medusa’nın Salı”, TÜY, 4,91 m x 7,16 m, 1817-18, Louvre Müzesi

Gericault, olayın herhangi bir anını ele alabilirdi. Örneğin geminin kayalıklara oturması, salın filikalar tarafından çekilmesi, Saldaki bir çarpışma anı, kazazedelerin yamyamlığı, Argus'un salın yanında belirmesi, kazazedelerin Argus'a binme anları gibi olay örgüsünde bulunan herhangi bir anı temsiller yoluyla ifade edebilirdi (Barnes, 2018). ${ }^{3}$ Konu olarak salda kalan 15 kişiyi kurtaracak 'Argus' isimli geminin ufukta belirişini, saldakilerin geminin farkına vararak büyük bir umutla gemiye doğru yönelişlerini betimlemeyi seçmiştir. Sırada bu anın nasıl betimleneceği kalmıştı. ${ }^{4} \mathrm{O}$ halde bu felaket gerçeğine uygun nasıl gösterilecekti. Sanatçının elinde kazaya, kaza sonrası yaşananlara ve kazazedelerin kurtuluşuna dair verilerin de olması gerekiyordu.

Gericault, kazaya ilişkin ilk elden veri toplamak zorundaydı. İlk olarak geminin doktoru Henri Savigny ve coğrafyacı mühendis Alexandre Correard'ın tanıklığına başvurdu (Lee, 2012). Sanatçı, Savigny ve Correard'ın yazmış olduğu anıları okumakla yetinmemiş onlarla yüz yüze de görüşmeler yapmıştır. Ayrıca Salı inşa eden ustayı bularak, salın bir replikasını yaptırarak atölyesine koydurtmuştur.

Resmi yapmaya başlamadan, resim ile ilgili yapacağı şeyleri düşündüğü esnada çizdiği gerçek ceset parçalarını atölyenin ötesine berisine serpiştirmiştir (Leppert, 2017, s. 227). ${ }^{6}$ Bu resimler, salın üzerindeki çarpışmalar sonucu ortaya çıkmış olan manzarayı duyumsamak ve resmi oluşturacak duygu yoğunluğunu iyice aksettirmek isteğinden kaynaklanıyordu. Bu uzuvların çizimi aynı zamanda Bourbon Restarasyon Döneminde bolca kullanılan giyotin ile idam edilmeye olan karşıtlığını ve idam edilme eyleminin vahşetini de sembolize eder. Tablonun en tepesinde

\footnotetext{
${ }^{3}$ Barnes, Gericault'un bu tür sahnelere ait ön çalıșmalarının olduğunu ancak konuyu en etkili kılacak sahnenin bu olduğuna belirtir. Açıklayıcı olması açısından dinsel bir konuya da atıfta bulunarak, Tanrı'yı en iyi betimleyecek sahnenin Tufan öyküsü olmadığını daha çok Meryem'e Müjde, Cennettten Kovulma, Kıyamet Günü, gibi sahnelerin Tanrıyı betimlemede daha etkili olduğuna vurgu yapar. Bakınız: Julian Barnes, Gözünü Açık Tutmak, İstanbul, Ayrıntı Yayınları, 2018.

${ }^{4}$ Dönemde anlık veya hareketli görüntüleri kaydeden cihazlar olmadığından, sanatçı trajediye tanıklık eden kişilerin bilgisine başvuracaktı.

${ }^{5}$ Savigny, Correard ve Salı inşa eden marangozun portreleri nihai tabloda yer almaktadır. Barnes, kaza sürecinde yaşadıklarını ızdırabı canlandırırken ne hissettikleri sorusunu parantez içerisinde okuyucuya sorar.

${ }^{6}$ Richard Leppert bu ceset parçalarının çizimleri ile ilgili Kallmyer'in farklı görüşlerinin olduğundan söz ediyor. Bakınız: Nina

Altharassoglou Kallmyer, 'Gericault's Severed Heads and Limbs: The Politics and Aesthetics of Scaffod', Art Bullettin 74, 1992 , s. 599-618.
} 
elinde beyaz bez parçasını sallayan kişinin Zenci kökenli olması sanatçının Fransız yayılmacılığına, sömürgeciliğine karşı bir tavrı olarak da yorumlanabilir.

Resimde o halde tam olarak ne resmedildi. Resimden ve olay örgüsünden de açık bir şekilde de anlaşılacağ gibi, umudunu yitirenler geride kaldı, onlar resmedilmedi. Umudunu yitirmeyenler, yaşama sıkı sıkı sarılanlar resimde betimlendi (Barnes, 2018). Tablonun en altından başlayan umutsuzluk, Rönesans’tan beri aşına olduğumuz üçgen kompozisyonun tepesinde yerini umuda bırakır. ${ }^{7}$ Tablo, aynı anda hem umut hem umutsuzluk duygularını üzerinde barındırır.. Geminin onları görmeden gitme ihtimaline karşı acı, kazazedelerin kendilerini gördürtme çabalarının hissedildiği hem panik hem de sevinç atmosferi vardır.

Medusa'nın salında olanlar "Kierkegaard'ın umudun sonsuz olanı ortaya çıkarması, gelecekle bağ kurması ve kişinin kendisi olması görüşü” paralelinde incelenebilir (Gülten, 2014). Kurtuluş umudunu taşıyan kazazedeler, saldaki çarpışmalara, şiddetli firtınalara göğüs germiş, umudunu yitirenler ise ya kendi istekleri ile okyanus sularına atlamış ya da çarpışmalarda yaşamını yitirmiştir. Kişinin kendisi olması sadece bireyselliğin ön plana çıkarılması şeklinde değil, insanın bilinçaltında yatan vahşiliğin, saldırganlığın ve şiddetin gün yüzüne çıkması olarak ta algılanmalıdır. "Gabriel Marcel; kişinin umut veya umutsuzluk arasında bir seçim yaptığı, umutsuzluğa düşen kişinin de güven duygusundan yoksun olacağını ve kendi beninden uzaklaşacağından bahseder" (Koç, 2008, s. 172). Salda yaşanan trajedi Marcel'in bu tespitini doğrular.

Umutsuzluk durumu Marcel'de karanlıktan aydınlığa çıkma durumudur. Son kertede kaza hikayesinde belirtilen karanlık firtınalı gecelerin, uzun aç ve susuz günlerin ardından uzakta görülen bir geminin kazazedeler üzerinde yarattığı etkisi, kazazedelerin yönelimi, hareketi, umutsuzluktan umuda yönelimleri tıpkı karanlıktan aydınlığa çıkma anını betimler. ${ }^{8}$ Marcel; "Her umut kurtuluşa yönelik umuttur." der (Koç, 2008, s. 178). Umut, sonunda ortaya çıkacak şeye yöneliktir. İki boyut (harekete geçme ve sonuç) birlikte ele alınır. Biri olmadan ötekisi zaten ele alınamaz.

\subsection{Hatay'ın Anavatan'a Hasreti}

İngiltere ve Fransa; Birinci Dünya Savaşı sırasında karşılıklı imzalamış oldukları Sykes Picot Antlaşması ile Suriye, Lübnan ve Hatay (İskenderun) Fransa'ya bırakılmıştı. 1918 de Mondros Antlaşması ve 1920 tarihli Misak1 Milli'ye göre bu bölgenin Türkiye'nin ulusal sınırları içerisinde kalması gerekmiştir. Savaşın getirmiş olduğu koşullar nedeniyle Hatay 20 Ekim 1921 tarihli Ankara Antlaşması ile Suriye sınırları içerisinde bırakılmıştır. Bu antlaşmaya göre Hatay'da Türkçe resmi dil olarak kullanılacak, Türk nüfusun kültürü korunacak ve geliştirilecektir (Atabey, 2015, s. 193). Bu antlaşma ve maddeleri Türkiye'nin Hatay üzerinde daha sonra hak iddia etmesinin önünü açmıştır. Türk Kültürünün geliştirilmesi maddesi, Hatay’ın çoğunluğunu oluşturan Türklerin kendi benliklerinin korumalarını sağlamıştır. Süreç içerisinde Hatay Türkleri, Türkiye’ye katılma isteklerini sürekli dile getirmiş ama bu istek Fransız makamlar tarafından şiddetle reddedilmiştir.

Jeopolitik bir konuma sahip olan Hatay, 1936'da başlayan tartışmalı süreçte, başarılı bir dış politika izlenerek, önce Hatay'a bağımsızlık verilmesi, 1939'da da Anavatan'a bağlanması gibi çift planlı bir yol izlenmiştir (Karakoç, 2009). Atatürk'ün deyişiyle 40 asırlık Türk yurdunun Türkiye sınırları dışında bırakılması, batının orayı başka bir coğrafyaymış gibi algılamalarının aksine, bu Türk yurdunun sahipleri kendi benliklerini koruyarak bir zamanlar bağlı oldukları Anavatan'a karşı özlemleri ve ona katılıp bütünleşme umutları hiç bitmemiştir. Oluşan bu kısa süreli ayrılık, duygusal olarak bir enerji yaratmıştır. Bu duruma sanatçılarda kayıtsız kalmamışlardır.

İnsan doğasının en önemli tarafı, hikaye anlatımı gibi köklü içsel gereksinimlerinin olmasıdır. Bu hikayecilik sadece dil üzerinde yürümez. İlk mağara resimleri, Ortaçağ heykelleri, romantik manzaralar, expressif ağaç oymalar hep bu ifade isteği ile inşa edilmiştir. Resim sanatının konularının başında gelen 'Alegori' göründüğünden daha derin anlamları olan görsel temsillerdir. Alegori bize görünen görüntünün ötesinde ki anlamları tanıdık imgelerle bize sunar. "Alegori, betimlenecek olan şeyin, bireyselleştirilerek doğada onu reel olarak temsil etmeyen biçimlerde gösterilmesidir” (Turani, 2015, s. 10). Konuyu ve kompozisyonu oluşturan öğeler yaşam, ölüm, aşk, erdem, adalet gibi konuları daha derin ahlaki ve manevi anlamı sembolize etmesi için kullanılır.

Kendini ve sanatını ülkesine adamış olan İbrahim Çallı; 1933 yılında kendini Hatay'ın yerine koyarak onunla özdeşleşmiş onu Anavatan'ına bakar vaziyette bir Anadolu kadını olarak, alegorik olarak resmetmiştir. (Görsel 2) Bu resimde Çallı'nın bize yansıtmış olduğu bireysel bir tavır olmaktan çıkar, o dönemde tüm Hatay'da hissedilen

\footnotetext{
${ }^{7}$ Resimdeki tasvirde ressam kompozisyona olan katkısı ve yaşanan trajediyi daha etkili kılabilmek için salın ön taraflarına serpiştirdiği 4 ceset bulunmaktadır. Kazazedeler kurtarıldığında bu cesetler salın üzerinde yoktu, ressam bunları sonradan eklemiştir.

${ }^{8}$ Resimde bu açıkça bellidir. Koyu alanlardan güneşin doğduğunun veya battığının tam olarak anlaşılamadığı bir aydınlığa doğru gider. Argus'ta bu aydınlık içerisinde bir kurtarıcı olarak beliriyor. Resmin altında başlayan, umutsuzluğu yansıtan göstergeler, resmin tepesinde yerini heyecana, harekete ve umuda bırakır.
} 
Anavatan’a katılmak için atılan sessiz çığlığın görsel bir imge vasıtası ile yerel-ulusal bir temsil ile aktarılmasına dayanir.

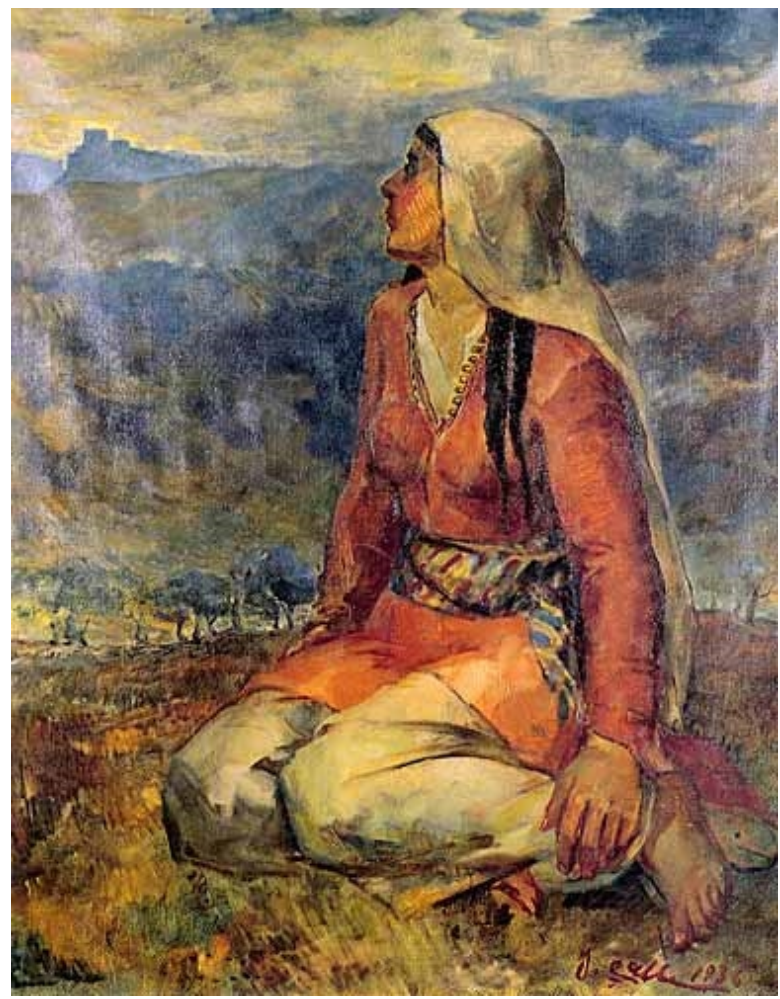

Görsel 2. İbrahim Çallı, “Hatay’ın Anavatan'a Hasreti”, TÜY, 1933

Gabriel Marcel'e göre kişi umutsuzluğu kendini sınırlama ve tutsaklık olarak gördüğünde, umutsuz durum doğal olarak ortaya çıkar. Kişinin bu duruma karşı tepki şiddeti ne kadar fazla ise umut o kadar artar, kendini tutsak ve sınırlanmış hissetmesi ne kadar az ise umudun şiddeti de o kadar azalır (Koç, 2008, s. 178). 'Hatay'ın Anavatan'a Hasreti" yapıtında da umut kavramı şiddetli, canlı nihai amacına ulaşmak için sabırsız ve bir o kadar da ağırbaşlı bir imge sunar. İmge, içinde bulunulan duruma karşı bir harekete geçme, mevcut durumuna karşı bir başkaldırı olarak yorumlanabilir. Hatay alegorisi de olması gereken durumuna, ait olduğu yere kavuşabilmesi için bir şeyler yapılması gerektiği, içinde olduğu durumun pek te kabul edilebilir bir şey olmadığını olumlu bir umut enerjisi, ağır başlı, dingin ve kararlı bir şekilde sunar. Hatay’ın alegorisi isteklidir, karşısına çıkabilecek engellere karşı 'aktif bir bekleyiş' halindedir. Düşündüğü, hayal ettiği ve kavuşma umudu sadece kalbi veya zihni bir eylem olarak kalmayacak, onun ötesine geçecektir. Nitekim Hatay’ın bekleyişi de uzun sürmeyecek 6 yıl sonra Anavatan’a katılacaktır.

\subsection{Umut Yolcuları: Mülteciler}

28 Ocak 2011 tarihinde Suriye'de başlayan kitlesel gösteri hareketleri, aynı yılın ağustos ayında iç savaşa dönüştü. Ülkedeki rejim karşıtı güçlerin oluşturduğu oluşumlar ile rejim güçleri arasında yaşanan çatışmalar halen devam etmektedir.

BM'ye göre şu ana kadar 400.000'den fazla masum insan öldürüldü, Ocak 2019'a kadar 5,6 milyon kişi ülke dışına kaçmak zorunda kaldı. 6 milyondan fazla kişide yerinden edildi. 3.400 .000 kişiye sınırlarını açan Türkiye başta olmak üzere Lübnan ve Ürdün'de ciddi bir mülteci kitlesine sahip. Türkiye'ye gelen bir kısım mültecide (Bu mültecilerin önemli bir kısmını Afganistan ve Pakistan kökenliler oluşturmaktadır) Ege denizinden Yunanistan'a geçerek Avrupa'ya ulaşmak için çabalamaktadır (“Global Conflict Tracker”, 2019). İç savaş kuşkusuz insanların daha güvenli ve daha iyi bir yaşam vaadinde bulunan bölgelere gitme hareketliliğini getirmiştir. Bu yer değiştirme yolculukları kendisi ile birlikte birçok trajedinin de yaşanmasına sebep olmuştur ve olmaktadır. 

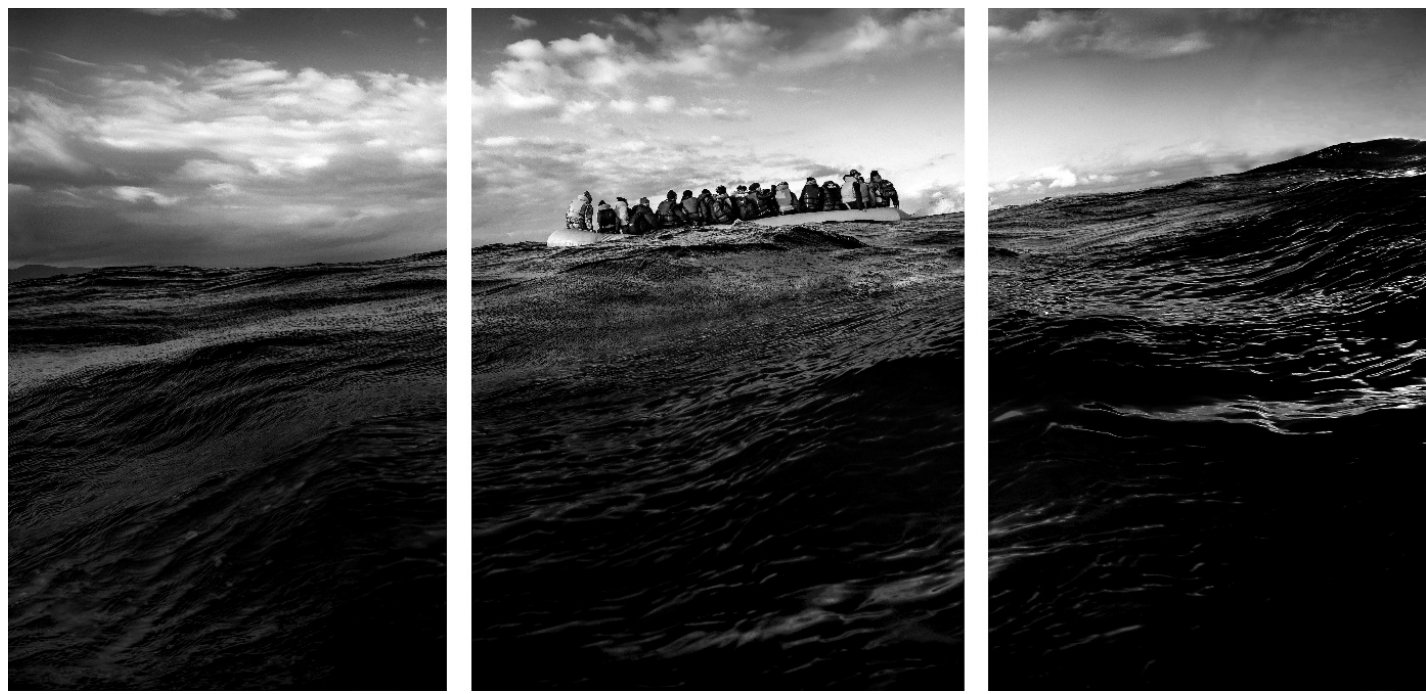

Görsel 3. Will Rose'un Ege Denizinde çekmiş olduğu mülteci botu, 2015

Robert Longo'nun Theodore Gericault'un “Medusa'nın Salı” nı çok iyi bildiğini biliyoruz. Ancak bu sefer bir gemiden geriye kalan trajedi değil, bir fotoğrafçının karesine yansıyan, sonsuz gibi görünen Ege Denizindeki mültecileri gösteriyor. Longo ayrica bir mültecinin sala binebilmesi için en az 2000 dolar ödemesi gerektiğini biliyor. Longo; resmindeki mülteciler ile izleyiciler arasındaki sınırı kaldırarak, izleyiciyi de ücretsiz sala binmeye davet ediyor (Dan, 2017).

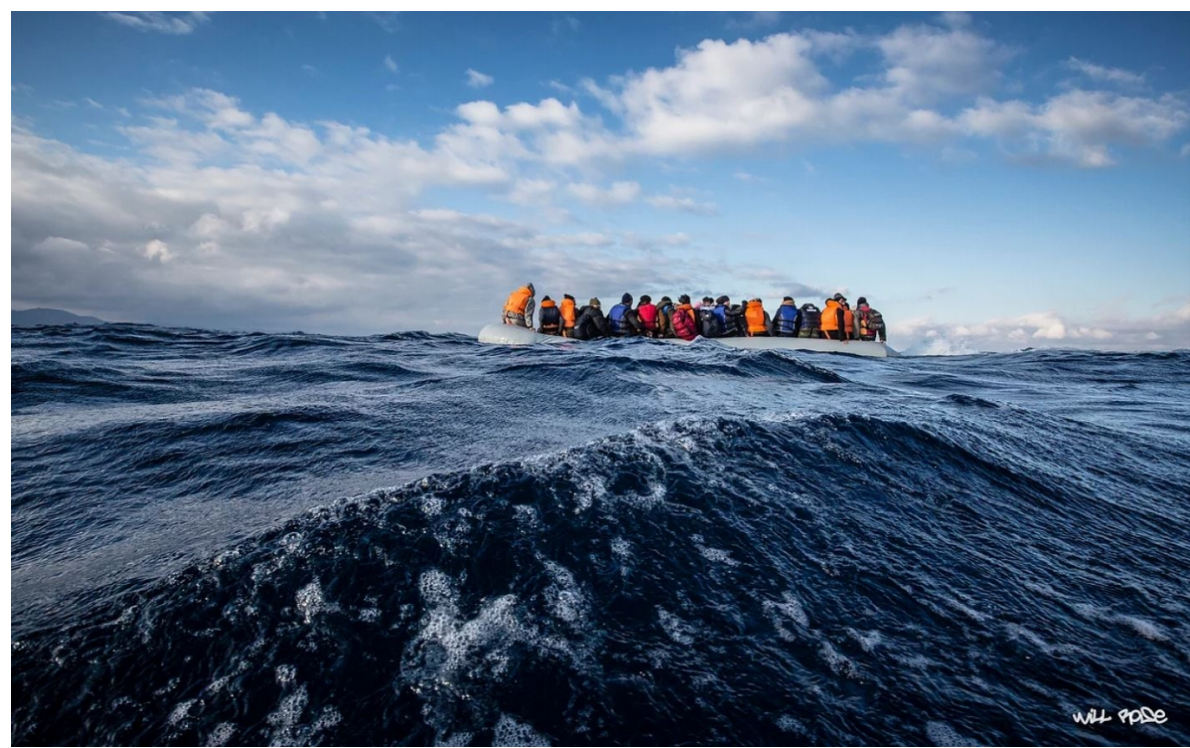

Görsel 4. Robert Longo, “İsimsiz (Denizde Sal)”, 355.6 x 713.74 cm, Kağıt Üzerine Kömür Kalem, 2017

Marcel; insanın kendi tutsaklığının üstesinden gelmek için harekete geçmenin gerekliliğinden bahseder. Bizi ilgilendiren şeylerin tehlikeye girmesi ile birlikte kişilerin risk alması ve bir şeyler yapması gerektiğini ileri sürer (Koç, 2008, s. 178). Bu durumu yaşayan insanlar için umut etme süreci de başlamış olur. Longo'nun eseri, kendi durumlarından rahatsız olan, hayatlarının pahasına da olsa risk alarak çıkmış oldukları yolculuğun sonucunda umut ettikleri şeye ulaşmaya çalışan kişileri temsil ediyor. Saldaki mültecilerin aktif olarak içinde oldukları durum, hayal ettikleri şeyi aşmıştır. Çünkü umut edilen şeyin hayalin ötesine geçmesi gerekir. Bunun için bir yolculuğa, umut yolculuğuna çıkmışlardır. Saldakilerin umut veya umutsuzluk arasında yapmış oldukları seçim, onları umut ettiklerine kavuşturacak veya kısır anlayışlar, sınırlar, ayrımcılık ile farklı bir trajediye bürünüp yeni umutları kendisi ile birlikte getirmesi olasılığını da bünyesinde barındıracaktır.

\section{Sonuç}

İnsanlık tarihi yaşanan olaylar ve sonrasında ortaya çıkan, insan varlığını tehdit eden olaylar ve durumlar nedeni ile kendine bir çıkış arayan insanlar, umudu kendi benliğinde doğal olarak hissettiği bir içsel durum olarak ortaya çıkmış, tarihin hangi durağında olursa olsun harekete geçirici en büyük güç olmuştur. Umudun harekete geçirdiği insanlar kendi yazgılarını değiştirmek için, her türlü riski ve engeli göz önüne alarak kendi kaderini tayin etmiştir. 
Tarihi süreç işte bu umut ve umutları uğruna harekete geçen insan hikayeleri ile doludur. Umudun harekete geçirdiği kişiler ve topluluklar yazgılarını kendileri yazmış, olumlu veya olumsuz sonuçlarına katlanmıştır.

Tarihteki bazı örnekleri anlayabilmek ve temellendirebilmek için harekete geçirici güçleri bilmek gerekmektedir. Süreçte ortaya çıkan örneklerine baktığımızda hepsi başlangıçta birbirinden farklı görünse de hepsinin ortak olduğu nokta, eylem ve hareket sonucunda ortaya çıkması beklenilen, umut edilen şey olduğunu görürüz.

Yaşanmış hikayeler umut kavramının nasıl ortaya çıktığını örnekler ve ona her kişide, toplulukta, ulusta ayırıcı bir kimlik kazandırır. İnsanoğlunun, daha iyi bir yaşam, tehlikelerden uzaklaşma, kendi güvenliğini sağlama, içinde bulunduğu, yaşadığı yazgıyı değiştirme dürtüsü hep umut ile güç kazanmış ve onu harekete geçirmiştir.

Tarih umudu doğuran koşulları yaratır, felsefeciler insanın umut konusunda eylem ve düşüncelerine ilişkin yargılar ileri sürerek kavramın içini teorik anlamda doldururlar. Kimisi umudun zararlı bir şey olduğunu düşünmüş, kimisi de onun insanı tamamlayan doğal bir parçası olduğunu ileri sürmüştür. Sanatçılar ise insanın, insanlığın umuda olan yönelimlerini ifade etmek için görsel temsilleri kullanmışlardır. Bazen üstü kapalı ve bazen de apaçık olarak bunu yapmışlardır. Hangi dönemde olursa olsun sanatçı duyarlığı olaylar karşısında kendi konumunu belirlemiştir. Hissettikleri ve yansıttı̆̆ı sadece o anı yaşayanlarla sınırlamamış, o kişilerin, topluluğun, ulusun o an umuda yönelik duygu ve hislerini evrensel bir dille temsilini sunmuştur.

Umudu betimleyen sanatçılar; kendi beninden, içerisinde yaşadıkları toplumdan veya başkalarının yaşadıkları gerçekliklerden hareketle, onların umuda bakışları, yönelimleri, duyguları ile özdeşleşerek kendi pencerelerinden resmetmişlerdir. Gericault, talihsiz bir deniz kazasında ölüm kalım mücadelesi veren kişilerin mevcut durumlarından kurtuluşları için taşıdıkları umudun doruk noktasına ulaştığı, bu umut anının yoğun olarak hissedildiği bir temsil sunarken, İbrahim Çallı; Türk Ulusunun topraklarının bir parçası olan Hatay'ın, Anavatan'a özlemi ve onunla bütünleşme umudunu taşıyan alegorik bir imge üzerinden tüm ulusun duygularını bizlere yansıtır. Robert Longo ise; evrensel kronik bir sorun haline gelmiş mülteciler ve göç konusunu ele almıştır. Kişileri, umut ettikleri yeni bir yaşam için koyuldukları bu zorlu yolda betimler. Salın üzerindekiler umut ettiklerini bilir ancak ulaşıp ulaşamayacaklarını bilmez haldedirler. Longo bu duyguya izleyiciyi de davet ederek ortak eder. Longo ve Gericault'ta umut algısı bir topluluk ve bu topluluğun parçası olan kişiler üzerinden betimlenirken, Çallı bir ulusun kollektif umudunu kișileştirerek daha kapsamlı bir betim sunar. Gericault, kișilerin kurtuluşları için taşıdıkları umuda, Longo, umut ederek harekete geçmiş kişilerin çıktığı yolculuğa, Çallı ise birbirinin parçası olan ve tekrar bir araya gelmeyi umut eden bir toplumun tümünün taşıdığı umut anlayışına vurgu yapar.

\section{Kaynakça}

Atabey, F. (2015). Hatay'ın anavatana katılma süreci. Avrasya Uluslararası Araştırmalar Dergisi, 4(7), $192-209$. doi: https://doi.org/10.33692/avrasyad.509271

Barnes, J. (2018). Gözünü açık tutmak, sanat üzerine denemeler. (S. R. Kırkoğlu, Çev.). İstanbul: Ayrıntı Yayınları.

Baxandal, M. (2015). 15. yüzyılda sanat ve deneyim stilin toplumsal tarihine giriş. (A. Artun, Dü., \& Z. Rona, Çev.). İstanbul: İletişim Yayınları.

Burke, P. (2003). Avrupa'da rönesans-merkezler ve çeperler. (U. Abacı, Çev.). İstanbul: Literatür Yayıncılık.

Dan, D. (2017, 31 Temmuz). Robert Longo ile söyleşi. Garage Magazine. Erişim Adresi: https://www. robertlongo.com/exhibitions/2016_Garage/2016-Garageinterview.pdf

Global Conflict Tracker. (2019, 23 Kasım). Civil war in Syria. Erişim Adresi: https://www.cfr.org/interactive/ global-conflict-tracker/conflict/civil-war-syria

Gülten, N. (2014). Kierkegaard'ta umutsuzluk, iman ve umut (Doktora Tezi). YÖK Tez veri tabanından erişildi (Tez No: 356719).

Hauser, A. (2006). Sanatın toplumsal tarihi (Cilt 2). (Y. Gölönü, Çev.). Ankara: Deniz Kitapevi.

Humphrey, N. (1998). Cave art, autism, and the evolution of the human mind. Cambridge Archaeological Journal, 8(2) 165-191. doi: https://doi.org/10.1017/S0959774300001827

Karakoç, E. (2009). Atatürk'ün Hatay davası. Bilig, 50, 97-118. Erişim Adresi: http://www.acarindex.com/ dosyalar/makale/acarindex-1423873181.pdf

Koç, E. (2008). Bir Umut Metafiziği Olarak Gabriel Marcel Felsefesi. SDÜ Sosyal Bilimler Dergisi, 18, $171-194$. Erişim Adresi: https://dergipark.org.tr/tr/download/article-file/118000 
Lee, G. K. (2012). All at sea: Romaticism in Gericault's Raft of the Medusa. Australien National Universty Undergraduate Research Journal. Erişim Adresi: https://press-files.anu. edu.au/ downloads/press / n 1674/pdf/book.pdf

Leppert, R. (2017). Sanatta anlamın görüntüsü. (3. Baskı). (İ. Türkmen, Çev.). İstanbul: Ayrıntı Yayınları.

Read, H. (2018). Sanat ve toplum. (E. Kök, Çev.). İstanbul: Hayalperest Yayınevi.

Russ, J. (2011). Avrupa düşüncesinin serüveni. (4. Baskı). (Ö. Doğan, Çev.). Ankara: Doğu Batı Yayınları.

Shiner, L. (2017). Sanatın icadı-Bir kültür tarihi. (4. Baskı). (İ. Türkmen, Çev.). İstanbul: Ayrıntı Yayınları.

Tan, N. (2014). Ne Umabilirim? Kant'ın Ahlak Felsefesinde Umut Kavramı. Fırat Üniversitesi Illahiyat Fakültesi Dergisi, 19(2), 49-66. Erişim Adresi: http://ilahiyat.firat.edu.tr/sites /ilahiyat.firat.edu.tr /files /dizgi 4\%2B\%20necmettin\%20tan.pdf

Toral, B. (2019, 10 20). Umut nedir ve neden kötüdür?. DÜŞÜN-Ü-YORUM. Erişim Adresi: http://www.dusunuyorumdergisi.com/umut-nedir-ve-neden-kotudur/?h=UMUT\%20NED\%C4\%B0R

Turani, A. (2015). Sanat terimleri sözlüğü. İstanbul: Remzi Kitabevi.

Türk Dil Kurumu. (2019, 20 Ekim). Şehit. Erişim Adresi: https://sozluk.gov.tr/?kelime=

Uygur, E., \& Uygur, F. (2014). Fransız sömürgecilik tarihi üzerine bir araştırma. Türkiye Sosyal Araştırmalar Dergisi, 173(173), 273-286. Erişim Adresi: https://dergipark.org.tr/tr/download/article-file/200454

Yılmazok, Ö. (2019, 12 12). Medusa'nın salı-Gericault. Sanata Başla!. Erişim Adresi: https://www.sanatabasla. com/2014/10/medusanin-sali-the-raft-of-the-medusa-gericault/

\section{Görsel Kaynakçası}

Görsel 1. Gericault, T. (Sanatçı). (1817-18). Medusa'nın Salı [Tuval Üzerine Yağlı Boya]. Erişim Adresi: https://www.louvre.fr/en/oeuvre-notices/raft-medusa

Görsel 2. Çallı, İ. (Sanatçı). (1933). Hatay’ın Anavatan'a Hasreti [Tuval Üzerine Yağlı Boya]. Erişim Adresi: http://ressamlar.grafiksaati.org/ibrahim\%20calli/ibrahim_calli_5.htm

Görsel 3. Rose, W. (Gazeteci). (2015). Ege Denizinde Mülteci Botu [Fotoğraf]. Erişim Adresi: http://www.rosesjolander.com/lesvos

Görsel 4. Longo, R. (Sanatçı). (2017). İsimsiz (Denizde Sal) [Kağıt Üzerine Kömür Kalem]. Erişim Adresi: https://www.artsy.net/artwork/robert-longo-untitled-raft-at-sea 